\title{
New Directions \\ In The Nigerian Educational System
}

Duro Ajeyalemi, University of Lagos, Akoka-Yaba, Nigeria

Ayodele. O. Ogunleye, University of Lagos, Akoka-Yaba, Nigeria

\begin{abstract}
In recent times, the Nigerian educational system has witnessed some drastic reforms. This paper highlights some of the major reforms that have taken place especially in response to a number of international human rights instruments that provide for education as a fundamental human right to all. The paper further discusses some of the challenges facing education in Nigeria and which is making it difficult for good quality education that is all empowering and capable of bringing about sustainable development to be achieved. Finally, it offered some suggestions on how to overcome these challenges.
\end{abstract}

Keywords: Educational Reforms, Quality Education, Empowering, Sustainable Development, Fundamental Human Rights Instruments, Universal Basic Education.

\section{INTRODUCTION}

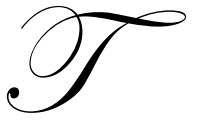

he importance of education to any nation cannot be over emphasized. It is in recognition of this importance that the international community and governments all over the world have made commitments for citizens to have access to education. Education is a human right that should be given to all human beings. In recent times, there have been quite a number of international human rights instruments that provide for education as a fundamental human right to all. Some of these instruments include the Universal Declaration of Human Rights (1948), the International Covenant on Economic, Social and Cultural Rights (1966) and the African Charter on Human and Peoples' Rights (1981).

The major trigger activity for a basic education programme in the 1990s was the World Conference on Education For All (WCEFA), which was held in Jomtien, Thailand from 5-9th March 1990. The World Bank, UNDP, UNESCO organized this conference and UNICEF as they came up with a document entitled "World Declaration on Education For All and Framework for Action to meet basic needs". The communiqué of the conference stated clearly in Article 1 that every person - child, Youth and Adult - shall be able to benefit from educational opportunities designed to meet their basic needs. This declaration was reaffirmed at the World Summit for Children also held in 1990, which stated that all children should have access to basic education by the year 2000. This World Summit for Children placed a lot of emphasis on raising the levels of female literacy. These documents, therefore, became a blue print for all countries of the world, including Nigeria, to step up education activities to achieve Education For All (EFA). Furthermore, in recent times the culture of globalisation has equally engendered new social and economic reforms, such that many countries of the world are redefining their educational goals and priorities in other to complete effectively in the emerging global village. As a result, many countries are signatories to some global reforms. Two such goals are the Millennium Development Goals (MDG) and the Education For All (EFA) Goals. The Millennium Development Goals (MDGs) was adopted in September 2000 at the United Nations Millennium Declaration has two of the eight goals devoted to education. They are goal 2 (to achieve universal primary education) and goal 3 (to promote gender equality and empower women).

- $\quad$ Eradication of extreme poverty and hunger

- $\quad$ Achievement of universal primary education

- $\quad$ Promotion of gender and women empowerement

- $\quad$ Reduction of child mortality 
- Improvement of maternal health

- $\quad$ Combating HIV/AIDS, malaria and other diseases

- $\quad$ Ensuring environmental sustainability

In a bid to achieve education goals, the Dakar World Education Forum was held as a follow-up meeting to the WCEFA where new sets of goals were set, to be attained by the year 2015. The goals include:

(i) Expanding and improving comprehensive early childhood care and education, especially for the most vulnerable and disadvantaged children;

(ii) Ensuring that by 2015 all children with special emphasis on girls, children in difficult circumstances and from ethnic minorities have access to and complete free and compulsory primary education of good quality;

(iii) Ensuring that the learning needs of all young people and adults are met through equitable access to appropriate learning and life skills programmes;

(iv) Achieving a 50 percent improvement in levels of adult literacy by 2015, especially for women, and equitable access to basic and continuing education for all adults;

(v) Eliminating gender disparities in primary and secondary education by 2005 and achieving gender equality in education by 2015, with a focus on ensuring girls' full and equal access to and achievement in basic education of good quality;

(vi) Improving all aspects of the quality of education and ensuring excellence for all so that recognized and reasonable learning outcomes are achieved, especially in literacy, numeracy and essential life skills.

Over the years, Nigeria has expressed a commitment to some of these instruments in education with the strong belief that overcoming illiteracy and ignorance will form a basis for accelerated national development. These two globally emerging goals have far reaching implications for restructuring and reforming education in most countries of the world. Nigeria, being a signatory to both the MDG and the EFA goals, made the Federal Government of Nigeria to establish in 2004 the National Economic Empowerment and Development Strategy (NEEDS). According to Obioma (2006), the critical elements of NEEDS are:

- Value orientation

- $\quad$ Poverty eradication

- Job creation and employment generation

- $\quad$ Empowering people through education in other to achieve the first three goals follows:

Some of the implications of the NEEDS reform measures for the Nigerian educational system are as

\author{
- $\quad$ Enhancement of access \\ - Improvement of quality \\ - $\quad$ Reviewing and renewing the curriculum periodically \\ - $\quad$ Promotion of ICT capabilities \\ - $\quad$ Encouragement of public-private partnership
}

According to Igbuzor (2006), the poor state of education in Nigeria is aptly captured in the National Empowerment Development Strategy as follows:

...the delivery of education in Nigeria has suffered from years of neglect, compounded by inadequate attention to policy frameworks within the sector. Findings from an ongoing educational sector analysis confirm the poor state of education in Nigeria. The national literacy rate is currently 57 percent. Some 49 percent of the teaching force is unqualified. There are acute shortages of infrastructure and facilities at all levels. Access to basic education is inhibited by gender issues and sociocultural beliefs and practices, among other factors. Wide disparities persist in educational standards and learning achievements. The system emphasizes theoretical 
knowledge at the expense of technical, vocational, and entrepreneurial education. School curricula need urgent review to make them relevant and practice oriented.

For Nigeria to be able to achieve the targets of MDGs and EFA, a number of new policies and new directions have emerged. In this paper, I will highlight some of the recent reforms at each of our levels of the educational system in Nigeria and show how these reforms are consistent with these goals. Furthermore, I shall highlight some of the challenges that flow from such reforms and finally offer some useful suggestions.

\section{NEW DIRECTIONS IN PRIMARY EDUCATION}

Since 1960, when there was a continental conference in Addis Ababa, African countries have been committed to universal primary education. At that conference, 1980 was set as the target year for the achievement of universal primary education. Although this goal was not met, enrollment was far greater than the projections had suggested it would be. In 1976, the Federal Government of Nigeria committed itself to universal primary education (UPE), a move seen as a means of working toward the equalization of educational opportunities by providing a minimum level to which all children would be educated. Even though, the UPE program was as a success in that millions of Nigerian children were able to received a primary education, however, over a twenty-year period the UPE programme faced many problems. According to Tahir (2000) include:

Overstretched facilities and overcrowded classrooms

Population explosion in recruitment into schools;

Imbalances in educational attainment

Unqualified and untrained teachers;

Poor remuneration in teachers' wages leading to poor motivation and low morale;

Little or no plans for career development for teachers;

Inflexible curricula;

Inadequate supervision of schools

\section{THE UNIVERSAL BASIC EDUCATION (UBE) PROGRAMME}

In order to ensure total eradication of illiteracy in the country through the provision of education for all, the Federal Government of Nigeria introduced the Universal Basic Education (UBE) programme on September 30, 1999. in response to the challenges in the primary education sector. The UBE is a governments' response to addressing the distortion in the basic education sector so as to ensure an unfettered access to basic education and improve the quality of its provision.

The aims and objectives of the Universal Basic Education (UBE) include among others to:

(i) develop in the entire citizenry a strong consciousness for education and strong commitment to its vigorous promotion;

(ii) provide free compulsory Universal Basic Education for every Nigerian child of school-going-age;

(iii) reduce drastically drop out rate from the formal school system through improved relevance and efficiency;

The UBE scheme has three major components. These are:

(i) Formal basic education encompassing the first nine years of schooling (Primary and Junior secondary education for all children).

(ii) Nomadic education for school age children and education for migrant fishermen.

(iii) Literacy and non-formal education for out of school children and illiterate adults.

The Federal Government through an Act of 2004 established formally the Universal Basic Education Commission in other to successfully implement the programme. Furthermore, the Government also established an intervention fund for the smooth implementation of the UBE programme in the states. By this Act, State UBE Boards (SUBEB) and Local Government Education Agencies (LGEA) were equally established through state edicts. 
Specifically, the Universal Basic Education Act (2004) and the Child Rights Act provide the legal framework for the implementation of the Programme, which makes basic education not only free but also compulsory. In addition, as a signatory to the 2000 World Education Conference, and the 6 Dakar Goals towards achieving Education for All (EFA), Government has also established a National EFA Coordination unit under the Federal Ministry of Education mandated to prepare a National Action Plan for the delivery of EFA in Nigeria.

From September 2006, Nigeria formally commenced the systematic implementation of the 9-year basic education programme (an integration of primary and junior secondary schools (JSS) with regard to the school curricula). This programme is supposed to ensure that pupils remain in school for 9 years of continuous study, will be driven by the adoption of the new 9-year basic education curricula. It is envisaged that the curricula will be systematically introduced in year 1 of the 6-year primary school and year 1 of the 3-year JSS, and by the year 2015, the 9-year basic education curricula will become fully operational in the school system in Nigeria

The philosophy of the 9 - year basic education curricula is to ensure that every learner who has gone through 9 years of basic education should have acquired appropriate levels of literacy, numeracy, manipulative, communicative and life- skills; as well as the ethical, moral, and civic values needed for laying a solid foundation for life-long learning The 9-year basic education curricula will focus on strategic basic contents for the achievement of the country's reform initiatives in value-orientation, poverty eradication, and wealth generation and job creation.

\section{IMPLEMENTATION STRATEGIES}

The following are some of the strategies that are expected to be put in place for the successful implementation of the programme:

- The complete disarticulation of JSS from SSS and transforming all primary schools into 9-year basic education schools.

- $\quad$ The development of school curricula for the 9-year basic education programme. The 9-year basic education curriculum structure has already been approved by the National Council on Education (NCE) meeting at Ibadan in December 2005.

- The introduction of a selection and screening examination into the SSS, such that only JSS graduates who pass this selection examination will be able to proceed to SSS.

- $\quad$ All JSS graduates of the 9-year basic education programme at age 15 years should be fully equipped with strategic work skills and have the potential of benefiting from life long continuing education.

- $\quad$ Proposed vocationalisation of the 3-year post basic education (SSS) in the context of curriculum restructuring. The 3-year post basic education (SSS) programme is to be geared towards preparing learners for productive work as well as for higher education in the NEEDS context.

- The contents of the SS3 will be integrated in a continuous manner to that of the 100 level university, polytechnic and college of education. This will enable learners who are tertiary education bound to be well grounded and in the process assure a smooth transition

- $\quad$ The reformed SSS curricula will take account of emerging issues in the NEEDS.

- $\quad$ Review of existing primary, JSS and SSS texts in the context of these reform measures

- $\quad$ Planned use of ICT in teaching and learning. Government intends to systematically introduce e-learning beginning with basic education. This will commence with automating the school curriculum and preparing electronic texts.

- $\quad$ Building the capacity of schoolteachers in new ways of teaching and in coping with the restructured school curricula. The Universal Basic Education Board in concert with SUBEBs and LGEAs are to commence massive orientation of teachers in the use of the new basic education curricula.

- $\quad$ Providing various roles and responsibilities among the major stakeholders in basic education. Such that basic education shall be a collective responsibility, with communities assuming more responsibility .This way, consensus will be built and shared or common vision and aspiration engendered.

The UBE can therefore be regarded as an educational intervention programme which is designed to eradicate illiteracy, ignorance and poverty as well as stimulate and accelerate national development, political 
consciousness and national integration. Many problems however may be identified as possible impediments to the successful implementation of the UBE programme. These problems along with others that have been identified by scholars over the years include:

- In- conducive school environment.

- Inadequate infrastructural facilities

- $\quad$ Lack of instructional materials especially textbooks

- $\quad$ Widening gap between funding needs and actual allocation.

- $\quad$ Funds (from government) do not flow down to the schools.

- $\quad$ Incidence of untrained teachers

- $\quad$ Head teachers have no administrative powers and authority over their staff.

- $\quad$ Teacher - pupil ratio is about 1:76, which is indicative of the numerical inadequacy of the teachers.

- $\quad$ Dissatisfaction of teachers with their remuneration and working conditions.

- $\quad$ Total absence of in- service training or professional development schemes for teachers.

- Imbalances in enrolment figures between male and female with boys constituting $56 \%$ and girls $44 \%$. Statistics indicate glaring imbalances against girls in enrolment, attendance and completion rates in all levels of education in Nigeria, particularly in the northern parts of the country, due to a variety of sociocultural and religious factors. It means that the rights of millions of children, especially girls, will be violated.

\section{NEW DIRECTIONS IN THE ADMINISTRATION OF UNITY SCHOOLS}

Unity Schools were established by the government in all States to strenghten the unity of this Nation. These schools since they were established 40 years ago have raised generations of leaders from divers backgrounds and ethnic groups. The vision of the Unity Schools is a powerful one motivated by a strong desire to build one nation.

However, in recent times, there has been moves by the Federal government to privatise the schools but with an assurance from the Ministry of Education that it would maintain a regulatory role with strict guidelines for the management of the schools defined and agreed upon. The move to privatise the Unity Schools is part of the ongoing reform in the education sector.

According to the Minister of Education, Dr. Ezekwesili, "The capacity of the 40-year-old model to achieve the noble dreams of earlier decades in the light of modern Nigeria's impinging constraints has caused the vision to fossilize," adding that many of the schools are now sub-standard with the absence of basic infrastructure and amenities, and have become "a sorry sight in the landscape of secondary education."

Dr. Ezekwesili further said: "Our greatest concern however, is the fact that the ministry spends an inordinate amount of time and resources on these schools that constitute only 30 per-cents of the secondary schools in the country. Out of 6.4 million secondary school students only 120,718 are in the 102 Unity Schools. This number cannot on any account justify the disproportionate amount of staff and budget allocated to these schools. This has to be reversed. We have to do things differently as the current business model can no longer be sustained."

Many stakeholders believe however that if the Unity Schools are privatised, the school fees would increase and the Unity Schools would thence be only for the students from rich homes as the students from poor homes will withdraw, thereby limiting further access to secondary education. Furthermore, there is also the vested interest by some people in the echelon of the society who run private schools but have less students and then want government to privatise all government schools so that they will have enough students in their schools.

The Association of Senior Civil Servants of Nigeria (ASCN), through its National President, Comrade Olakunle Olaitan cautioned against the sale of the schools, saying that their privatisation would be a dissavervice to the nation, politically and morally. Presdent Olusegun Obasanjo has however assured that there is no plan to sell the 102 Unity schools in the country. At a Presidential Forum on education in Abuja attended by all stakeholders including governors, traditional rulers, of students, representatives Committee of Vice-Chancellors and Chairmen of governing councils of universities, Nigerian Union of Teachers, academic and non-academic union of tertiary 
institutions, principals of secondary schools, Parents/Teachers Associations (PTA), Manufacturers Association of Nigeria (MAN), examination bodies like NECO, the President declared: "Ownership of Unity Schools will not change. Federal Government owns the Unity Schools that will not change. Management will be Public/Private Partnership, because to me, if you are managing and I am regulating, and I am monitoring, we are part of management."

Describing education as a service and which will remain so, he added: "But we want to get value for money, we want to manage it well, we want to ensure that it favours us at the end of it. Education is so serious and so important that we must all put our eyes on it." According to him, to reform education, the Education Ministry must itself be reformed. He hinged sustenance of his government's reforms on education. "Education is critical. Education must be one very important key and instrument for sustaining our reforms.

By opting to privatize the 102 Federal government colleges' spread all over the country or by changing their administration, the Federal government must have taken the right decision, as it no business establishing private schools in the first instance. Ordinarily, secondary education should not be the concern of the Federal goverment, under a Federation. The general idea is that government should worry less about running outfits that could be better managed by non governmental people, while the authorities busy themselves with enacting broad framework to facilitate the success of the private endeavours.

However, one issue that will surface in government's proposal is the matter of who buys the schools, at what price and how is the buyer determined? Going by previous experiences when government officials use fronts to win contracts and to buy government houses and property, the fear is already expressed that the schools will ultimately find their way into the hands of some government official or officials. After the sale, we can expect a few scandalous revelations.

\section{NEW DIRECTIONS IN UNIVERSITY POST JAMB SCREENING EXERCISE}

Perhaps, the state of coma into which the Nigerian education has relapsed could be better underscored by the inverse relationship between most candidates' scores in JAMB examinations and their performances in the postJAMB examination. Hitherto, Admission to universities is highly competitive and based on results from the Senior Secondary Certificate Examination, in which the students must gain at least a pass in English and four other courses relevant to the department to which they are seeking admission. Students who have the necessary SSCE results are eligible to sit for the University Matriculation Examination (UME) (introduced in 1978) and conducted by the Joint Admissions Matriculation Board (JAMB). Students sitting the UME must register for English language and any three subjects based on their desired major. A fifty percent score is considered a pass; however, different universities have different minimum requirements based on different majors.

It will be recalled that before the introduction of the post-JAMB screening exercise last year, Joint Admission and Matriculation Board (JAMB) was the sole body, determining the fate of prospective candidates into the nation's tertiary institutions. It is sad to note that today, however, that JAMB may have lost its glory and credibility due to what many refer to as the 'Nigerian factor'. Whatever that means or connote, the introduction of the post-JAMB screening exercise is another in the series of new directions in the Nigerian educational system. The objective of this reform is to ensure that only deserving candidates who would be able to benefit, are admitted to the universities.

In recent times, many Universities had reported poor correlation between performance in the classroom and UME results especially among candidates with the higher UME scores. This has contributed to the poor quality of university graduates in Nigeria. In order to ensure good quality new entrants (input) into the Nigerian universities, the Federal Government introduced the post-UME screening with effect from the 2005/2006 academic session. Various stakeholders, however, opposed the post-JAMB screening exercise. In response to this, the former Minister of Education, Mrs Obaji expressed surprise that some people could oppose government efforts to ensure that future graduates of Nigerian tertiary institutions were those that could be competitive at home and abroad, said that the problem of quality in tertiary education in the country was one that needed every one's contribution towards finding a permanent solution. 
The Federal government however reiterated it's believe that the post JAMB screening of candidates by the universities must stay, as it was not aimed at denying any Nigerian the benefits of University education. Instead, the aim was to ensure that candidates who cheated in anyway to secure high JAMB scores were eliminated at the last point of entry. Furthermore, the screening exercise is to bring quality and sanity into the system by insisting that universities adhered strictly to the carrying capacities allocated to them. The post JAMB screening is also one of the efforts at stemming the slide in the quality of university and Polytechnic education.

The results of Post JAMB screening conducted by some universities confirmed the generally expressed opinion by the universities that students' performance in Universities has no correlation with JAMB scores that qualified them for courses they were admitted to read.

\section{NEW DIRECTIONS IN PRIVATE PARTICIPATION IN EDUCATION}

Some of the changes in educational policy in respect of private participation in education could be traced to the Nigerian Federal Constitution of 1979 and the 1977 National Policy on Education revised editions of 1981, 1998 and 2004.

Many arguments have been put forward to support private participation in education. Some scholars are of the belief that private participation in education is a social responsibility. It is an obligation, which individuals, entrepreneurs and corporate organizations owe to the society, particularly in communities where they reside, operate and make their wealth. From the economic point of view, other scholars believe that government alone is incapable of providing all the education required by the citizens. This is because education is a very expensive enterprise, and no matter how rich a nation may be, it usually finds that there is a limit to which it can allocate its resources to education.

There is also the philosophical argument that private participation in education provides options for choice for the citizens. Thus, any educational system that seeks to develop qualitatively, and not merely to grow and expand, should encourage private entrepreneurs and bodies to contribute and participate actively in the provision, organization and administration of education.

Today in many states of the federation and the Federal Capital Territory, Abuja, there exists many private primary and secondary schools. Some of these schools are owned by church groups while a good number belong to private entrepreneurs. The Roman Catholics, Anglicans, Pentecostals and Moslems are all proprietors of private (schools. There are also many private primary and secondary schools maintained wholly or partly by serving and retired public servants. Many Nigerians, have embraced private participation in education, however, there are still many issues to be resolved. These include:

- $\quad$ The quality of instructions in the private schools, especially how they can adequately prepare their students to perform creditably in "learning and character". Furthermore, the rates at which the private schools are springing up like mushrooms everywhere gives room for concern.

- $\quad$ The effect of the impact of the Universal Basic Education (UBE) programme which provides a nine-year free and compulsory primary and junior secondary education for all Nigerian children of school age, 6 to 15 years in terms of maintaining standards, funding, teacher retention, etc.

The placement of higher education under the concurrent list in the 1979 Constitution allowed state governments to establish private universities. There are currently 26 such state universities in the country. Furthermore, Private sector participation in university education also commenced during the Second Republic. However, in the absence of proper guidelines for their establishment, they all turned out to be universities only in name. As a result the Federal Government abolished many of the early 24 private universities established between 1980 and 1983 in 1984, but nine years later, the Federal government promulgated Decree 9 of 1993, which allowed the establishment of private universities and spelt out procedures for their establishment. Six years after the promulgation of Decree 9 of 1993, the first set of private universities namely: Igbinedion University, Okada; Babcock University, Ilishan-Remo; and Madonna University, Okija, were licensed. This was to be followed by the licensing of five more private universities between $31^{\text {st }}$ July 2001 and $28^{\text {th }}$ May 2003. In 2005, another set of fifteen 
(15) private universities were established and to date there exists seventy-five universities in Nigeria consisting of 26 Federal, 25 state and 24 private universities.

The ownership of the 24 private universities in Nigeria is presently dominated by religious organisations. Fifteen of these private universities is owned by three major religious organisations. The Orthodox/Pentecostal Church organisations have 9: the Catholic Church organisations have 3, while the Islamic organisations have 3.

\section{NEW DIRECTIONS IN TERTIARY EDUCATION SYSTEM IN NIGERIA}

The tertiary education sector is provided by universities, polytechnics, institutions of technology, colleges of education and professional institutions.

In recent years there has been significant changes within the tertiary education system in Nigeria. At the University level, there has been significant increase in the number of universities and programmes offered in these institutions. So also are the explosion in student population and the number of aspirants seeking university admissions. According to NUC figures, the total student enrolment in all Nigerian universities grew from just over 2000 in 1962 to over 750,235 in 2006. Other notable changes in the tertiary education sector include:

- $\quad$ The development of Benchmark and Minimum Academic Standards (BMAS)

- $\quad$ The enforcement of carrying capacity for universities

- $\quad$ Establishment of the National Open University of Nigeria to create more access for students.

- $\quad$ Establishment of more private universities

- $\quad$ Establishment of the Nigerian Experts and Academics in the Diaspora Scheme (NEADS).

- $\quad$ Increased funding of universities

- Rehabilitation of infrastructures

At the Colleges of Education and Polytechnics level, significant changes are noticeable in the large number of students that are being admitted. For the avoidance of doubt, the mission of Colleges of Education in Nigeria is to produce highly motivated and skilled NCE teachers worthy in character and learning through effective teaching, research and public service for the basic education system. Furthermore, to ensure uniformity in standards in the colleges, minimum standards have been developed for each programme or subject-area.

At the Polytechnics level, one major reform has been given approval is the need to restructure the National Diploma (ND) programme so that it covers a total period of three (3) years, to provide for a one-year industrial attachment, following two years of academic work.

\section{NEW DIRECTIONS IN TEACHER EDUCATION}

The professionalization of teaching is a new direction in teacher education and is a good development in the history of education in Nigeria. The Teachers Registration Council of Nigeria (TRCN) was established to regulate the profession and give it a pride of place by providing new code of conduct for teachers and also make arrangements for their continued professional development. Already, TRCN has indicated that all unqualified serving teachers who have begun to avail themselves of the various opportunities for upgrading to the acceptable level for registration by the end of 2006 would remain in service and be encouraged to complete their training while others who do not possess registerable teaching qualifications have been encouraged to take advantage of the NUC/UNESCO Higher Education Pedagogy Training programme online to acquire pedagogical skills.

In Nigeria the need for well qualified teachers has gained pre-eminence because it is considered that teacher education is a means of not only providing teachers with the necessary skills and knowledge needed to adequately carry out their teaching jobs as well as for professional growth. Teacher education programs in Nigeria are under the supervision and control of governmental organizations. The National Commission for Colleges of Education (NCCE) has responsibility for teacher education in Nigeria with respect to Colleges of Education. At present there are 61 Colleges of Education, of which 20 are controlled and funded by the Federal Government, 38 by state governments, and three are owned by private agencies (see Table.1). 
Table 1: List of Institutions that Run Teacher Education Programs in Nigeria

\begin{tabular}{|l|c|}
\hline \multicolumn{1}{|c|}{ Institutions } & Numbers \\
\hline Federal Colleges of Education (Regular) & 11 \\
\hline Federal Colleges of Education (Technical) & 8 \\
\hline Federal Colleges of Education (Special) & 38 \\
\hline State Collages of Education & 3 \\
\hline Private Colleges of Education & 9 \\
\hline Polytechnics with NCE Programs & 43 \\
\hline Universities with Teacher Education Programs & 2 \\
\hline
\end{tabular}

\section{CHALLENGES FACING EDUCATION IN NIGERIA}

There are a lot of challenges facing education in Nigeria and making it difficult for good quality education that is empowering and capable of bringing about sustainable development to be provided.

The first and perhaps the greatest challenge facing education is inadequate funding by federal, states and local governments, to the extent that funding has been in response to conditionalities imposed by international financial institutions (IFIs).

Financing education in Nigeria will need to consider some strategies that (i) deploy available resources with optimal effectiveness and (ii) encourage community and parental contributions to education development. Increased cost effectiveness will require, first, reducing the variation in the level of allocation of resources, in particular in teacher-pupil ratios, among schools. Second, it will require enhancing efficiency by spending resources on those inputs and processes that are known to be strongly supportive of student learning.

The second is improving quality. Quality is a multi-faceted concept. Most definitions highlight the different elements of the basic input-process-output model that commonly underpins education research and policy analysis (UNESCO, 2002). Some recent research studies suggest quality improvement framework for schools rests on seven principal pillars:

- Create the opportunity to learn: Ensure that essential inputs and supplies are in place and encourage home support and school readiness.

- Improve instructional practice: Implement a relevant curriculum, develop competent teachers, help head teachers to become instructional leaders and pay special attention to effective instruction in the early years.

- Manage the challenge of equity: Reach out to learners with an array of delivery mechanisms, ensure equitable opportunities to learn for poor children (especially those in rural areas), address the gender challenge and recognize diversity and flexibility in design and provision as essential.

- Increase school autonomy and flexibility: Deconcentrate authority to regional and district offices, move towards school-based management, support head teachers as transformational leaders, but recognize monitoring, supervision and support as essential for school improvement.

- Nurture community support: Recognize that quality emerges from the interaction of parents, communities and schools, encourage broad community involvement and foster communities as partners in school development.

- Ensure a realistic financial framework:

The third is the problem of access, which has attracted a lot of attention particularly in recent years. The central question that should agitate our minds is the implication of open access to the future direction of the nation's education system. 
Access to schooling is a function of three basic considerations. These are:

- $\quad$ Availability of school and its physical proximity to child's home;

- $\quad$ The actual and regular running of the school as a teaching-learning centre;

- $\quad$ the value attached to the school by the community both in terms of its worthwhile perspective of what is taught and the credibility of those who impart learning.

These three variables are what we regard as the fundamental determinants of real access. In other words, availability of physical facilities alone, without a credible curriculum and competent teachers to ensure its delivery, neither ensures nor improves access to education. These factors must be pursued pari passu by government if genuine access to schooling is to be achieved. What is usually seen happening in Nigeria, is the pursuance of the provision of the classrooms to accommodate the expected enrolment, while little attention is paid to teacher preparation and motivation as well as ensuring the regularity of teaching and learning in the schools.

Fourthly, there is the problem of poor infrastructures and lack of teaching and learning materials. A huge number of primary, secondary and tertiary school buildings and facilities are dilapidated and unfriendly to pupils. The environment of teaching and learning is not conducive. To provide a real opportunity to learn, sufficient instructional materials will have to be available to every student. Teachers should be prepared to use these materials, have knowledge of effective instructional practice, and be ready to adopt and adapt such practices. Effective teaching and learning require wide and equitable availability of learning materials. In Nigeria, this is not the case. This situation calls for urgent attention, including the rethinking of policies governing production and distribution of textbooks and other learning materials and the training of teachers in how to use learning materials more effectively.

Finally, there is the problem of irrelevant curriculum. A relevant curriculum is one that connects learning to the child's experience and environment, makes learning meaningful, responds to parental expectations and demands, and at the same time prepares students not only for today's world but also for society as it will develop in the next fifty years. In a rapidly changing globalised world that demands a capacity for adaptation and innovation to pursue social and professional mobility and to invent new solutions for new situations, one of the most essential characteristics of a relevant curriculum is its flexibility (i.e., its openness and adaptability to both the needs of the local context and development for the future).

\section{WHAT IS TO BE DONE?}

In my view, what needs to be done to face the challenges of Education in Nigeria include:

- Improvement of teacher quality through employment of professional and qualified teachers, in service training and retraining and implementation of the teacher salary structure

- $\quad$ Tracking of resources to ensure proper, adequate and accountable utilization of resources budgeted for education

- $\quad$ Adequate funding which will be needed to build new schools, train more teachers, improve infrastructures at all levels.

- $\quad$ Proper governance of schools and implementation of Schools Management Committees (SMCs)

- $\quad$ Implementation of the UBE Act and ensuring that all forms of user fees are abolished

- Dealing with the quality issues including size of classes, number of teachers and provision of materials.

- $\quad$ Promotion of child friendly and teacher friendly school environment, and respect and protection of the rights of children in school including protection from violence in schools especially of the girl child.

\section{CONCLUSION}

In conclusion, if we are to achieve development goals, then our educational system must undergo major reforms. There is no doubt that the state of education in Nigeria is lamentably poor and there are a lot of challenges. But there are perspectives and approaches that can be utilized to turn the situation around. What needs to be done is clear. We need to rise up to the challenges and change the course of events in Nigeria and put education in a right footing. That is the only sure way to sustainable development. 
It is quite obvious that basic education in Nigeria had continued to respond to local and international dynamics in policy formulation and implementation; curriculum design and institutional reforms.

The renewed prominence and indeed the consistency with which the identified trends as universalizing access, quality, internationalization of education, and community ownership and control of schools have begun to appear, is bound to result into a drastic shift in focus of basic education delivery in the future. This calls for innovative, flexible and culturally acceptable approach in managing basic education by stakeholders, most especially government, practitioners and professionals, local and national interest groups.

Though government influence will continue to be dominant for some time to come, as a result of the need for ensuring universal access and quality, however, its influence will reduce gradually, until such a time that local councils, communities and other interest groups eventually take-over the control and ownership of the schools.

\section{AUTHOR INFORMATION}

Dr. Ayodele .O. Ogunleye is a teacher and science educator by profession. He is currently a Senior Lecturer in Science Education at the Faculty of Education, University of Lagos, Nigeria. He obtained M.Sc in Theoretical Physics, M. Ed in Science Education, M. Sc in Computing and IT and Ph.D. in Science Education. In addition, he earned a Diploma in Science Education from Chelsea College of Science and Technology, University of London. He was a Visiting Academic to the Institute of Education, University of London.

\section{REFERENCES}

1. EFA Global Monitoring Report (2002). Education For All: Is the World on Track. Paris: UNESCO

2. Federal Ministry of Education (2001). Country report of Nigeria. International Conference on Education, 46th session, Geneva,

3. Federal Republic of Nigeria (2005). Nigerian Millennium Development Goals. Abuja: National Planning Commission

4. Federal Republic of Nigeria. (2001) Education for All (EFA) in Nigeria. Country report on EFA since Dakar and National Plan of Action.

5. International Association of Universities (IAU) and Association of African Universities (AAU) (2002). Guide to Higher Education in Africa. New York: Palgrave.

6. Jibril, M. (2003) African Higher Education: An International Reference Handbook. Bloomington: Indiana University Press (492-499)

7. Saint, W., Hartnett, T., and Strassner, E. (2003). Higher Education in Nigeria: A status Report. Washington, D.C.: The World Bank

8. Obioma, Godswill (2006). Resources for Science, Mathematics and Technology (STM) Education in the context of Education reforms in Nigeria. Proceedings of the $47^{\text {th }}$ Annual Conference of STAN.

9. Otive Igbuzor (2006) The State of Education in Nigeria. Being a Keynote Address Delivered At A Roundtable Organised By Civil Society Action Coalition On Education For All (Csacefa) On $3^{\text {rd }}$ July, 2006. 
NOTES 